\title{
MATING PATTERNS IN THE APHIDOPHAGOUS LADYBIRD, HIPPODAMIA VARIEGATA, DEPEND ON BODY SIZE
}

\author{
AHMAD PERVEZ* and SANTOSH SINGH
}

Biocontrol Laboratory, Govt. Degree College, Talwari, Chamoli - 246482 (Uttarakhand), India

* Corresponding author: ahmadpervez@yahoo.com

\begin{abstract}
Body size dependent mating patterns were investigated in an aphidophagous ladybird, Hippodamia variegata (Goeze), which was reared on mustard aphid, Lipaphis erysimi (Kalt.). Both males and females of varying body sizes were used to test the hypothesis that bigger is better. The costs of copulation on the life history traits of the mating partners were determined. Pairs of virgin beetles were allowed to mate once under controlled conditions and the duration of copulation of heavy beetles ( $504.00 \pm 45.93 \mathrm{~min}$ ) lasted significantly longer for than that of light beetles $(270.00 \pm 26.67 \mathrm{~min}$ ). Body size was significantly positively correlated with duration of oviposition, fecundity and egg viability. When light individuals mated with heavy partners, copulation lasted longer between heavy males and light females (483.00 \pm $54.73 \mathrm{~min}$ ) than between light males and heavy females $(378.20 \pm 83.03 \mathrm{~min})$. These results support the hypothesis that males determine the duration of copulation and that the reproductive success of large males is greater than that of small males. The longevity of heavy males was significantly shorter ( $37.40 \pm 1.50$ days) than that of light males ( $53.10 \pm 2.84$ days). This difference in the longevity of beetles of different sizes could contribute to the significant variation body size in $\mathrm{H}$. variegata recorded both in the field and stock cultures, where light males outnumber heavy ones. Thus, although large males have a reproductive advantage over small males, other factors, such as reduced longevity, may constrain the evolution of even larger males.
\end{abstract}

Key words: reproduction, fecundity, mating duration, aphid, evolution, copulation

\section{Introduction}

Body size affects behaviour and performance of individuals in most animal species (Filin and Ovadia 2007). This could be true of insects that vary greatly in body size, especially in the same gender. Individual variation in body size can be an indicator of individual differences in competitive ability (Filin and Ovadia 2007). Large body size in females in most insects could be a result of natural selection maximizing fecundity, which results in female-biased sexual size dimorphism (Honek 1993; Head 1995). Such females are competitively superior, acquire more resources and are more fecund (Wall and Begon 1987; Belovsky et al. 1996). It is interesting to note that the frequency of small males is greater than that of large males in wild populations (Pervez, unpubl. data). Thus there is a significant variation in the body sizes of both genders. In predaceous ladybirds (Coleoptera: Coccinellidae) body size dependent sexual dimorphism is recorded in many species (Kawauchi 1979; Hodek and Honěk 1996).

In life-history theory body size is directly associated with reproductive effort and performance (Roff 1992). This theory predicts that reproductive effort should increase as life expectancy decreases (Roff 1992; Stearns 1992). However, there is little empirical evidence in support of this hypothesis. Thus, a study is needed that conclusively shows that life expectancy decreases with increase in reproductive activity. The cost associated with increased reproductive activity can be gender unbiased, or only one gender bears this cost. Fecundity advantage hypothesis states that egg production in most insects is positively correlated with body weight or size (Leather 1988; Heliovaara et al. 1990; Honěk 1993; Preziosi et al. 1996; Tammaru et al. 1996; Honěk et al. 2008). Hence, big females have a greater fecundity and reproductive activity than small females. Based on the above hypothesis the expectation is that life expectancy will decrease with fecundity, which needs to be addressed. Previous studies indicate that duration of mating affects fecundity and fertility (Obata 1987; Obata and Johki 1991; Omkar and Pervez 2005). Hence, in order to address the problem of body size dependent reproduction, duration of mating also needs to be taken into consideration.

Hippodamia variegata (Goeze) is an aphidophagous ladybird, which occurs in the hilly regions of North India and was used in the present study as an experimental model for addressing the above problem. It is a Palaearctic ladybird, which has successfully established itself worldwide (Natskova 1973; Belikova and Kosaev 1985; Gumovskaya 1985; Gordon 1987; Nicoli et al. 1995; Krafsur et al. 1996; Wheeler and Stoops 1996). There are a few studies on its predation potential (Fan and Zhao 1988; Obrycki and Orr 1990; Kalushkov et al. 1991; Sadeghi and Esmailli 1992; Singh and Singh 1994), but little is known about mating in this species. Female $H$. variegata mated only once can lay large numbers of eggs (Pervez unpublished data). However, its reproductive capacity is greatly enhanced if it mates more than once (Pervez and Maurice 2011). In this paper we determine whether 
body size affects the duration of copulation in this species of ladybird and if so which gender is most affected? Additionally, we also tried to determine whether there is a trade-off between life expectancy and reproduction and its evolutionary significance.

\section{Materials and methods}

\section{Stock maintenance}

Adults of $H$. variegata were collected from fields of Brassica campestris L. plants that were heavily infested with the aphid, Lipaphis erysimi (Kalt.) at Chamoli, North India, and brought to the laboratory. They were paired in Petri dishes $(2 \times 9 \mathrm{~cm}$ diameter $)$ containing an ad libitum supply of L. erysimi on twigs of mustard (B. campestris) plant and kept in an Environmental Test Chamber (REMI Instruments, India) at $25 \pm 2{ }^{\circ} \mathrm{C}, 65 \pm$ $5 \%$ R.H and 12L : 12D. The Petri dishes were checked daily for eggs, which were collected and monitored to determine how long it took then to hatch. After hatching, the neonates were transferred to muslin-covered beakers containing an ad libitum supply of aphids and reared to the adult stage. The emerging $\mathrm{F}_{1}$ adults were sexed by carefully examining their genitalia under a stereoscopic trinocular (Model SZB-46) connected to a personal computer. These adults were then kept in two groups, viz. heavy (males with body sizes ranging from 8 to $11 \mathrm{mg}$ and females ranging from 14 to $16 \mathrm{mg}$ ) and light individuals (males with body sizes ranging from 5 to $7 \mathrm{mg}$ and females ranging from 10 to $13 \mathrm{mg}$ ).

\section{Reproductive parameters of heavy and light beetles}

Ten-day-old virgin pair of ladybirds were kept together in a Petri dish (size and prey as above) and allowed to mate once. After mating, they were isolated and both genders were kept under close observation until they died. The duration of copulation, pre-oviposition period, oviposition period, fecundity, \% egg viability, male longevity and female longevity were recorded for each pair. The above data were subjected to a one-way ANOVA and the means compared using a Tukey's Honest Test of significance. Pearson's correlation coefficients of the relationship between mating duration, fecundity, \% egg viability and longevity, and body size in terms of weight were calculated using statistical software, SAS. The relationships between the different parameters and body size were subjected to linear regression analysis using SAS.

\section{Results}

The results revealed significant associations between body size and all the reproductive parameters studied (Table 1). The longest duration of copulation was recorded between heavy males and heavy females (504.00 \pm $45.93 \mathrm{~min}$ ). This was significantly longer than that recorded for light males and females $(270.00 \pm 26.67 \mathrm{~min})$. When light individuals were mated with heavy partners, the duration of copulation of heavy males with light females $(483.00 \pm 54.73 \mathrm{~min})$ was longer than that of light males and heavy females $(378.20 \pm 83.03 \mathrm{~min})$. There were significant positive correlations between oviposition period $(r=0.56 ; p<0.001)$, fecundity $(r=0.50 ; p<0.001)$ and female longevity $(r=0.40 ; p<0.01)$, and female body size. There were significant positive correlations between mating duration $(r=0.48 ; p<0.01)$, percentage egg viability $(r=0.46 ; p<0.01)$ and fecundity $(r=0.58$; $p<0.001$ ), and male body size. Oviposition period, fecundity and percentage egg viability were significantly greater for females that copulated with heavy than light males.

The reproductive advantage of heavy males resulted in a trade-off in longevity. Heavy males had a significantly shorter life $(37.40 \pm 1.50$ days) than light males $(53.10 \pm 2.84$ days). Male longevity was significantly negatively correlated with their body size $(r=-0.45$; $p<0.01)$. The relationships between mating duration, fecundity and longevity, and body size in terms of weight are presented in Figure $(1 \mathrm{a}-\mathrm{d})$. This reveals that mating duration was positively correlated with male body weight and fecundity was positively correlated with female body weight (Figure 1a,b). However, male longevity was negatively correlated with duration of copulation (Figure 1c). Similarly, male longevity was negatively correlated with male body weight.

Table 1 The duration of copulation, period of oviposition, fecundity, egg viability and male female longevities recorded for mating pairs of H. variegata of different body sizes (HM = Heavy Male, LM = Light Male, HF = Heavy Female, LF = Light Female).

\begin{tabular}{|l|c|c|c|c|c|c|}
\hline $\begin{array}{c}\text { Mating } \\
\text { Pair }\end{array}$ & $\begin{array}{c}\text { Duration of copulation } \\
\text { (in } \text { min) }\end{array}$ & $\begin{array}{c}\text { Oviposition Period } \\
\text { (in days) }\end{array}$ & $\begin{array}{c}\text { Fecundity } \\
\text { (in eggs) }\end{array}$ & \% Egg Viability & $\begin{array}{c}\text { Male longevity } \\
\text { (in days) }\end{array}$ & $\begin{array}{c}\text { Female longevity } \\
\text { (in days) }\end{array}$ \\
\hline HM and HF & $504 \pm 45.93 \mathrm{a}$ & $8.00 \pm 0.56 \mathrm{a}$ & $142 \pm 15.20 \mathrm{a}$ & $51.12 \pm 2.63 \mathrm{a}$ & $37.40 \pm 1.50 \mathrm{~b}$ & $69.90 \pm 2.11 \mathrm{a}$ \\
\hline HM and LF & $483 \pm 54.73 \mathrm{a}$ & $5.11 \pm 0.58 \mathrm{~b}$ & $94.60 \pm 1.19 \mathrm{ab}$ & $43.73 \pm 1.03 \mathrm{ab}$ & $34.50 \pm 1.30 \mathrm{~b}$ & $46.10 \pm 2.63 \mathrm{c}$ \\
\hline LM and HF & $378.20 \pm 26.26 \mathrm{ab}$ & $4.60 \pm 0.72 \mathrm{~b}$ & $85.60 \pm 16.69 \mathrm{~b}$ & $40.47 \pm 5.33 \mathrm{ab}$ & $47.10 \pm 1.30 \mathrm{a}$ & $56.20 \pm 2.07 \mathrm{ab}$ \\
\hline LM and LF & $270.00 \pm 26.67 \mathrm{~b}$ & $2.14 \pm 0.29 \mathrm{c}$ & $27.00 \pm 2.45 \mathrm{c}$ & $23.80 \pm 6.85 \mathrm{~b}$ & $53.10 \pm 8.97 \mathrm{a}$ & $64.10 \pm 1.53 \mathrm{ab}$ \\
\hline F-value & $6.96^{*}$ & $18.26^{*}$ & $13.47^{*}$ & $3.55^{* *}$ & $8.55^{*}$ & $23.63^{*}$ \\
\hline
\end{tabular}

Values are Mean \pm SD.

F-values are significant at ${ }^{*} \mathrm{P}<0.001$ and ${ }^{*} \mathrm{P}<0.05$; Tukey's test range $=3.80 ; \mathrm{df}=3,36$.

In each column, means followed by different letters are significantly different. 

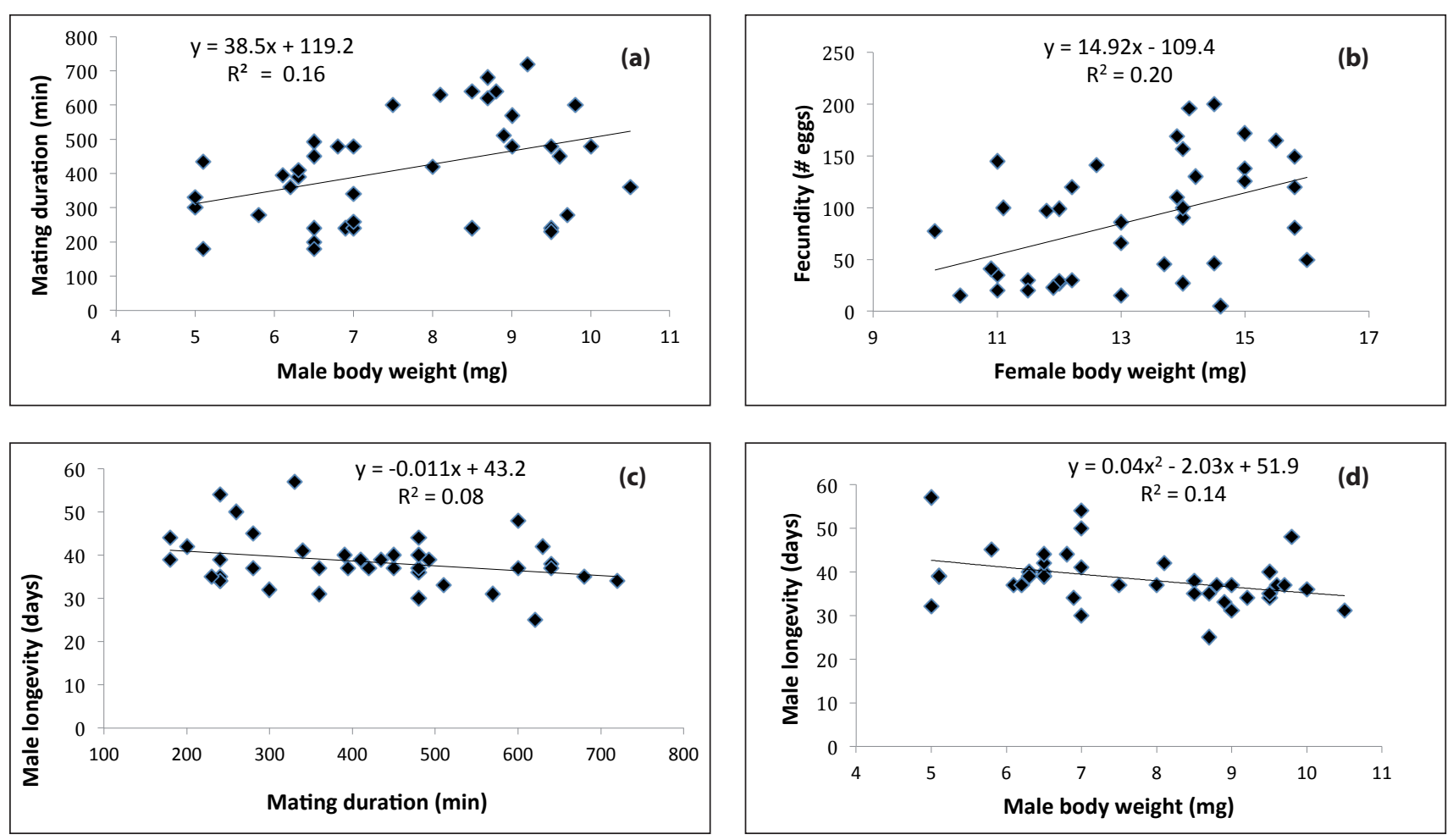

Fig. 1 Relationship between (a) mating duration and male body weight, (b) fecundity and female body weight, (c) male longevity and mating duration, and (d) male longevity and male body weight of $H$. variegata feeding on aphid, L. erysimi.

\section{Discussion}

It is evident from the results that the body size of adults has a significant role in mating and reproduction. We recorded exceptionally longer durations of mating for $H$. variegata than is recorded for similar sized or even any other ladybirds. Prolonged mating is reported for $P$. dissecta, where it ranges between 176-275 min (Omkar and Pervez 2005). Heavy adults copulated for longer than light adults, which supports our initial hypothesis that bigger is better. Amongst adults, mating with heavy males contributed more in terms of mating duration, which indicates that male body size could be the factor determining the duration of mating. Prolonged mating by heavy males indicates they may ejaculate a greater quantity of sperm (Pervez et al. 2004), which could result in a higher percentage egg viability. Prolonged mating in the ladybird, Propylea dissecta (Mulsant) results in a higher percentage of eggs hatching despite the fact that adults mate only once (Pervez 2002).

Mating between heavy males and heavy females resulted in both higher fecundities and egg viabilities compared to those resulting from mating between light males and light females, which again supports the hypothesis that bigger is better. The higher fecundity recorded for light females that copulated with heavy males indicate that the males are providing an excess of non-sperm substances which induce females to lay more eggs. For instance, in many insects, male seminal fluid proteins transferred during a female's first mating stimulate an increase in fecundity and decrease in receptivity to remating (Wolfner 2002; Sirat 2011). This provides the first male to mate with a female with the potential advantage of re-mating with the same partner. This, however, has not yet been recorded in ladybirds.

We recorded a positive relationship between fecundity and body weight. Heavy females were more fecund than light females, which supports the body size-fecundity advantage hypothesis. The fecundity and body size relationship is central to life-history models of age and size at maturity (Kozlowski 1992; Stearns 1992; Roff 2002). The low fecundity recorded in the present study is due to the fact that $L$. erysimi is not a preferred food of $H$. variegata (Omkar and Pervez 2004).

We recorded a significant negative correlation between the longevity of males and their body size, which clearly indicates a trade-off. The longevities of the heavy males were significantly shorter than those of light males. This trade-off, however, was not evident in females indicating that fecundity is not associated with their life expectancy. This is not the case in other insects in which high fecundity is associated with a shorter life expectancy in females (Partridge and Harvey 1985; Hunt et al. 2002). The decrease in male longevity could significantly affect the body size variation in $H$. variegata observed both in the field and stock cultures, as light males outnumber heavy ones (Pervez, unpubl. data). Although the reproductive benefits associated with large body size in males would appear to put them at a selective advantage, other factors such as reduced longevity may constrain further increases in their body size. In addition, large males may experience other costs, e.g. costs of dispersal and physiological maintenance when food is limiting, which are more likely to occur in 
wild populations. The cumulative effects of these factors may also constrain the evolution of larger males.

Thus, we conclude that: 1) heavy males mate for longer than light males, 2) females that mate with heavy males have a higher fecundity than those that mate with light males, 3) fecundity is a function of female body size, which supports the body size-fecundity advantage hypothesis, and 4) heavy males have a shorter life span than light males.

\section{Acknowledgements}

Authors are thankful to the University Grants Commission, New Delhi, India for financial assistance in the form a Major Research Project (No. F. 41-18/2012 [SR]). We also thank J.P. Michaud for critically going through earlier drafts and providing invaluable suggestions.

\section{REFERENCES}

Belikova EV, Kosaev EM (1985) The biology of the most important species of Coccinellidae and their role in controlling aphids in a cotton lucerne rotation. Biologicheskikh Nauk 5: 61-63.

Belovsky GE, Slade JB, Chase JM (1996) Mating strategies based on foraging ability: an experiment with grasshoppers. Behav Ecol 7: 438-444.

Fan GH, Zhao JF (1988) Functional response of Adonia variegata (Goeze) (Coleop., Coccinellidae) to cotton aphids. Nat Enemies Insects 10: 187-190.

Filin I, Ovadia O (2007) Individual size variation and population stability in a seasonal environment: A discrete time model and its calibration using grasshoppers. Amer Nat 170: 719-733.

Gordon RD (1987) The first North American records of Hippodamia variegata (Goeze) (Coleoptera: Coccinellidae). J New York Entomol Soc 95: 307-309.

Gumovskaya GN (1985) The coccinellid fauna. Zashchita Rastenii 11: 43 .

Heliovaara K, Vaisanen R, Varama M (1990) Fecundity and egg viability in relation to female body size in Neodiprion sertifer (Hymenoptera: Diprionidae). Holarct Ecol 13: 166-172.

Head G (1995) Selection on fecundity and variation in the degree of sexual size dimorphism among spider species (Class Araneae). Evolution 49: 776-781.

Hodek I, Honěk A (1996) Ecology of Coccinellidae. Kluwer Academic Publishers, Dordrecht Boston London.

Honěk A (1993) Intraspecific variation in body size and fecundity in insects: a general relationship. Oikos 66: 483-492.

Honěk A, Dixon AFG, Martinková Z (2008) Body size and the temporal sequence in the reproductive activity of two species of aphidophagous coccinellids exploiting the same resource. Eur J Entomol 105: 421-425.

Hunt J, Simmons LW, Kotiaho JS (2002) A cost of maternal care in the dung beetle Onthophagus taurus? J Evol Biol 15: 57-64.

Kalushkov PK, Dimova VI, Khristova AI (1991) Behavior of Adonia variegata (Goeze) (Coleoptera: Coccinellidae) in the search for prey. Ekologiya 24: 71-75.

Kawauchi SE (1979) Effects of prey density on the rate of prey consumption, development and survival of Propylea japonica Thunberg (Coleoptera: Coccinellidae). Kontyu 47: 204-212.

Kozlowski J (1992) Optimal allocation of resources to growth and reproduction: implications for age and size at maturity. Trends Ecol Evol 7: 15-19.
Krafsur ES, Obrycki JJ, Nariboli P (1996) Gene flow in colonizing Hippodamia variegata ladybird beetle populations. J Heredity 87: 41-47.

Leather SR (1988) Size, reproductive potential and fecundity in insects - things aren't as simple as they seem. Oikos 51: 386-389.

Natskova V (1973) The effect of aphid predators on the abundance of aphids on peppers. Rastitelna Zashchita 21: 20-22.

Nicoli G, Limonta L, Gavazzuti C, Pozzati M (1995) The role of hedges in the agroecosystem. Initial studies on the coccinellid predators of aphids. Informatore Fitopathologico 45: 7-8.

Obata S (1987) Mating behaviour and sperm transfer in the ladybird beetle, Harmonia axyridis Pallas (Coleoptera: Coccinellidae). Appl Entomol Zool 22: 434-442.

Obata S, Johki Y (1991) Comparative study on copulatory behaviour in four species of aphidophagous ladybirds. In: Proceedings of 4th Meeting of the IOBC W.G. Ecology of Aphidophaga, September 1990, Gödöllő, Hungary, 207- 212.

Obrycki JJ, Orr CJ (1990) Suitability of three prey species for Nearctic populations of Coccinella septempunctata, Hippodamia variegata and Propylea quatuordecimpunctata (Coleoptera: Coccinellidae). J Econ Entomol 83: 1292-1297.

Omkar, Pervez A (2004). Predaceous coccinellids in India: Predator-prey catalogue. Oriental Ins 38: 27-61.

Omkar, Pervez A (2005) Mating Behaviour of an aphidophagous ladybird beetle, Propylea dissecta (Mulsant). Insect Sci 12: 37-44.

Partridge L, Harvey PH (1985) Costs of reproduction. Nature 316: 20.

Pervez A (2002) Contribution on prey-predator relationship and reproductive biology of a colour morph of Propylea dissecta (Mulsant) (Coccinellidae: Coleoptera). Ph.D. Thesis, University of Lucknow, India.

Pervez A, Maurice N (2011) Polyandry affects the reproduction and progeny of a ladybird beetle, Hippodamia variegata (Goeze). Eur J Environ Sci 1: 19-23.

Singh D, Singh H (1994) Predatory potentiality of coccinellids, Coccinella septempunctata Linn. and Hippodamia variegata (Goeze) over mustard aphid, Lipaphis erysimi (Kalt.). Crop Res. Hisar 7: 120-124.

Preziosi RF, Fairbairn DJ, Roff DA, Brennan JM (1996). Body size and fecundity in the waterstrider Aquarius remigis: a test of Darwin's fecundity advantage hypothesis. Oecologia 108: 424-431.

Roff DA (1992) The Evolution of Life Histories. Theory and Analysis. New York: Chapman and Hall.

Sadeghi E, Esmailli M (1992) Preying habits and hibernation site of Coccinella septempunctata L., Hippodamia (Adonia) variegata (Goeze), Psyllobora vigintiduopunctata L. in Karaj. J Entomol Soc Iran 11: 5-8.

Sirot LK, Wolfner MF, Wigby S (2011) Protein-specific manipulation of ejaculate composition in response to female mating status in Drosophila melanogaster. PNAS doi.10.1073/pnas.1100905108

Stearns SC (1992) The Evolution of Life-histories. New York: Oxford University Press.

Tammaru T, Esperk T, Castellanos I (2002) No evidence of being large in females of Orygia spp. (Lepidoptera, Lymantriidae): larger is always better. Oecologia 133: 430-438.

Wall R, Begon M (1987) Population density, phenotype and reproductive output in the grasshopper, Chorthippus bruneus. Ecol Entomol 12: 331-339.

Wheeler AG Jr, Stoops CA (1996) Status and spread of the Palaearctic lady beetles Hippodamia variegata and Propylea quatuordecimpunctata (Coleoptera: Coccinellidae) in Pennsylvania, 1993-1995. Ent News 107: 291-298.

Wolfner MF (2002) The gifts that keep on giving: Physiological functions and evolutionary dynamics of male seminal proteins in Drosophila. Heredity 88: 85-93. 